\title{
Pendidikan Karakter Berbasis Keagamaan (Studi Kasus di SDIT Nur Hidayah Surakarta)
}

\author{
Fauzi Annur \\ Mahasiswa Pascasarjana IAIN Salatiga \\ e-mail: fauziannur18@gmail.com
}

\begin{abstract}
Until now, the education system in our country is more emphasis on the cognitive aspect than educating for character. Meanwhile, the globalization in $21^{\text {st }}$ has given rise to the phenomenon of free trade, dependence science and technology (ICT, Bio-technology, Nano-technology), global life (Speed, Conectivity, Intangable, and Compatibility), human rights, issues of democratization, environment, gender, and multiculturalism. SDIT Nur Hidayah is a school has applied to try appliying character building. These programs of character building is implementating from their own religion. This research uses descriptive qualitative. Subject of these researchs are teachers and students. And informan of these researchs are headmaster, employees, and parents of the children. The results of this research shows that the information program of the characters in SDIT Nur Hidayah Surakarta applied intensively (daily, weekly, monthly). The programs include 1. integrated in the leraning process, 2. any other programs: Pekan Pembiasaan, Pekan Kedisiplinan, Mentoring, Mutaba'ah Alyaumiyah. The purpose of these programs is intended to build characters of the students. These programs are not only comprehensive, but also very unique. The children are so enjoy and enthusiastic in carrying out various characters, and we hope they have a basic foundation of strong character.
\end{abstract}

Keywords: Character Building, based on Religion 


\section{Pendahuluan}

Pendidikan merupakan salah satu aspek yang sangat berpengaruh terhadap tingkat kemajuan suatu masyarakat dan bangsa. Kemajuan di bidang inilah yang selalu hendak dicapai oleh setiap bangsa dan yang pada akhirnya akan menjadikan bidang pendidikan tetap eksis di era perkembangan ilmu dan teknologi yang demikian pesat ini. Perkembangan zaman yang begitu pesat ini pula menimbulkan berbagai masalahmasalah baru yang harus segera diselesaikan. Untuk itu masalah pendidikan merupakan masalah yang sangat krusial dan urgen untuk selalu dibicarakan secara intensif dan berkesinambungan. Karena hanya melalui pendidikan yang bermutu, peradaban suatu masyarakat dan bangsa akan terus maju.

Sampai saat ini sistem pendidikan di negara kita masih lebih banyak menekankan aspek kognitif/akademik, seperti Ujian Nasional dibandingkan menekankan pendidikan karakter (M. Furqon Hidayatullah, 2010:15). Sementara itu, gelombang perubahan era global di abad ke-21 telah memunculkan fenomena perdagangan bebas, ketergantungan Iptek (ICT, Bio-teknologi, Nano-teknologi), kehidupan global (Speed, Conectivity, Intangable, and Compatibility), isu demokratisasi, HAM, lingkungan hidup, gender, dan multikulturalisme (Direktorat Jenderal Pendidikan Dasar, Kemdiknas:2011).

Padahal kalau dicermati lebih dalam lagi bahwa untuk memajukan pendidikan suatu bangsa, selain diperlukan sumber daya manusia yang cerdas, namun juga kecerdasan moral. Kecerdasan intelektual saja tidaklah cukup tanpa dibarengi dengan kecerdasan moral yang kokoh. Individu yang memiliki kecerdasan intelektual yang tinggi namun tidak bermoral akan menimbulkan akibat yang fatal dan dapat merugikan orang lain.

Tantangan pendidikan dewasa ini untuk menghasilkan SDM yang berkualitas dan tangguh semakin berat. Pendidikan tidak cukup hanya berhenti pada memberikan pengetahuan yang paling mutakhir, namun juga harus mampu membentuk dan membangun sistem keyakinan dan karakter kuat setiap peserta didik sehingga mampu mengembangkan potensi diri dan menemukan tujuan hidupnya. Pendidikan di sekolah tidak lagi cukup hanya dengan mengajar peserta didik membaca, menulis, dan berhitung, kemudian lulus ujian dan nantinya mendapatkan pekerjaan baik. Sekolah 
harus mampu memutuskan apa yang benar dan yang salah (M. Furqon Hidayatullah, 2010:22).

Untuk mengatasi itu semua diperlukan pendidikan yang dapat mengembangkan potensi individu sekaligus membentuk generasi yang bermoral dan berakhlak mulia. Singkat kata, bahwasannya tujuan pendidikan haruslah mengarah pada pengembangan berbagai karakter manusia Indonesia, bukan pendidikan akademik semata (Dharma Kesuma, 2011:8).

Ada tiga ranah tujuan pendidikan yang dapat di-inversi dari makna yang terkandung dalam pasal 1 (3) dan pasal 3 UU No. 20 Tahun 2003 tentang Sisdiknas, salah satu ranah tujuan pendidikan tersebut adalah: "Watak dan peradaban bangsa yang bermartabat dan berlandaskan nilai-nilai pancasila dan agama sebagai tujuan eksistensial pendidikan yang melandasi pencerdasan kehidupan bangsa sebagai tujuan kolektif yang di dalamnya mengandung kecerdasan kultural, karena kecerdasan kehidupan bangsa bukanlah agredasi kecerdasan perorangan atau individual". Pasal di atas menunjukkan serta menjadikan landasan legal formal akan keharusan membangun karakter bangsa melalui upaya pendidikan.

Sementara itu melalui Kementerian Pendidikan Nasional sudah mencanangkan penerapan pendidikan karakter untuk semua tingkat pendidikan, dari SD-Perguruan Tinggi. Menurut Mendiknas, Prof. Muhammad Nuh, pembentukan karakter perlu dilakukan sejak usia dini. Jika karakter sudah terbentuk sejak usia dini, maka hal tersebut akan menjadi sebuah kebiasaan positif dimasa mendatangnya. Ia juga berharap, pendidikan karakter dapat membangun kepribadian bangsa. Mendiknas mengungkapkan hal ini saat berbicara pada pertemuan Pimpinan Pascasarjana LPTK Lembaga Pendidikan Tenaga Kependidikan (LPTK) se-Indonesia di Auditorium Universitas Negeri Medan (Unimed), Sabtu (15/4/2010).

Pada hakekatnya pendidikan karakter yang telah dimaksudkan di atas sebenarnya tidak jauh berbeda dengan model pendidikan yang sudah pernah digagas dan dikembangkan oleh Fourster (1869-1966) yaitu model pendidikan yang berbasis nilai-nilai. Agama merupakan salah satu dari sumber nilai yang disepakati jika kita merujuk pada falsafah negara pancasila, pancasila menempatkan Ketuhanan Yang Maha Esa pada Sila Pertama, hal ini berarti nilai-nilai agama, nilai-nilai Ketuhanan mewarnai 
bagi sila-sila berikutnya dan dalam segala aspek kehidupan berbangsa dan bernegara. (http://meditekom.wordpress.com/).

Sementara itu di dalam agama Islam, pendidikan karakter merupakan misi utama Muhammad SAW ketika diutus menjadi Nabi atau dengan kata lain adalah untuk menyempurnakan akhlak manusia. Al-Quran adalah buku ajarnya di dalam menghadapi peserta didik masyarakat Arab yang ketika dulu sangat jahiliyah. Dimulai dari perintah membaca, karakter Islam dibentuk kemudian perlahan-lahan diingatkan untuk bangun dari selimut, menghayati pergantian alam semesta, menghargai sesuatu dengan kodratnya dan membersihkan perilaku. Bahkan perintah ritual ibadah (shalat, zakat, puasa, haji) dikaitkan dengan tumbuhnya karakter yang baik (Bambang Q-Anees, 2008:100).

Pendidikan akhlak di atas dijabarkan lagi menjadi butiran-butiran karakter yaitu sidiq, amanah, fathonah, tabligh, dan lain-lain. Karakter-karakter yang dicontohkan Muhammad SAW seperti inilah yang pada akhirnya dapat merubah keadaan zaman jahiliyah menuju zaman terang benderang.

SDIT Nur Hidayah Surakarta merupakan lembaga sekolah yang telah menerapkan pendidikan karakter berbasis keagamaan. Dari visi-misinya terlihat sangat terang mendengungkan karakter-karakter dan akhlak yang harus ditanamkan sejak dini. Tulisan ini berusaha menggambarkan proses pendidikan karakter yang SDIT Nur Hidayah sendiri merupakan sebuah institusi yang berbasiskan agama.

Rumusan masalah pada penelitian ini adalah bagaimana penerapan pendidikan karakter berbasis keagamaan di SDIT Nur Hidayah Surakarta? Adapun tujuan penelitiannya adalah untuk mengetahui penerapan pendidikan karakter berbasis keagamaan serta memberikan gambaran secara umum kepada praktisi pendidikan dan kepada masyarakat luas tentang penerapan pendidikan karakter berbasis keagamaan.

\section{Pendidikan Karakter}

Menurut T. Ramli (2003), pendidikan karakter memiliki esensi dan makna yang sama dengan pendidikan moral dan pendidikan akhlak. Tujuannya adalah membentuk pribadi anak, supaya menjadi manusia yang baik, warga masyarakat, dan warga negara yang baik. Adapun kriteria manusia yang baik, warga masyarakat yang 
baik, dan warga negara yang baik bagi suatu masyarakat atau bangsa, secara umum adalah nilai-nilai sosial tertentu, yang banyak dipengaruhi oleh budaya masyarakat dan bangsanya. Oleh karena itu, hakikat dari pendidikan karakter dalam konteks pendidikan di Indonesia adalah pedidikan nilai, yakni pendidikan nilai-nilai luhur yang bersumber dari budaya bangsa Indonesia sendiri, dalam rangka membina kepribadian generasi muda.

Sedangkan menurut Ahmad Sudrajad (2008:3) pendidikan karakter adalah suatu sistem penanaman nilai-nilai karakter kepada warga sekolah yang meliputi komponen pengetahuan, kesadaran atau kemauan, dan tindakan untuk melaksanakan nilai-nilai tersebut. Pendidikan karakter dapat dimaknai sebagai "the deliberate use of all dimensions of school life to foster optimal character development".

Hal yang senada juga diungkapkan olah Yahya Khan (2010:1) bahwa pendidikan karakter mengajarkan kebiasaan cara berfikir dan perilaku yang membantu individu untuk hidup dan bekerja sama sebagai keluarga, masyarakat, dan bernegara dan membantu mereka untuk membuat keputusan yang dapat dipertanggungjawabkan.

Dalam pendidikan karakter di sekolah, semua komponen (pemangku pendidikan) harus dilibatkan, termasuk komponen-komponen pendidikan itu sendiri, yaitu isi kurikulum, proses pembelajaran dan penilaian, penanganan atau pengelolaan mata pelajaran, pengelolaan sekolah, pelaksanaan aktivitas atau kegiatan ko-kurikuler, pemberdayaan sarana prasarana, pembiayaan, dan ethos kerja seluruh warga sekolah/lingkungan. Di samping itu, pendidikan karakter dimaknai sebagai suatu perilaku warga sekolah yang dalam menyelenggarakan pendidikan harus berkarakter.

Dari beberapa pendapat tersebut maka dapat disimpulkan bahwa pendidikan karakter adalah suatu sistem penanaman nilai-nilai cara berfikir dan berakhlak di dalam kehidupan sehari-hari yang bertujuan untuk membentuk pribadi anak agar mampu bekerja sama dengan seluruh komponen masyarakat. Lebih dipertegas lagi oleh Ratna Megawangi (2004:105) "Pendidikan karakter ini merupakan cara yang paling efektif membentuk perilaku seseorang, yaitu sesuai atau mengacu kepada standar nilai-nilai moral yang mana semua kelompok masyarakat mengakui nilai-nilai kebenaran tersebut".

| Volume. 1, No. 1, Januari - Juni 2016 


\section{Aspek-Aspek di dalam Pendidikan Karakter}

Menurut Lickona dalam (Ratna Megawangi, 2004:108) menekankan akan tiga komponen karakter yang baik yaitu pengetahuan tentang moral atau moral knowing, perasaan tentang moral atau moral feeling dan perbuatan bermoral atau moral action. Hal ini diperlukan agar peserta didik mampu memahami, merasakan dan sekaligus mengerjakan nilai-nilai kebajikan.

Moral Knowing adalah hal yang penting untuk diajarkan, hal ini terdiri dari enam hal yaitu: 1) Moral Awareness, 2) Knowing Moral Values, 3) Perspective Taking, 4) Moral Reasoning, 5) Decision Making, 6) Self-Knowledge. Adapun Moral Feeling adalah aspek lain yang harus ditanamkan kepada anak yang merupakan sumber energi dari diri manusia untuk bertindak sesuai dengan prinsip-prinsip moral. Terdapat enam hal yang merupakan aspek emosi yang harus mampu dirasakan oleh seseorang untuk menjadi manusia yang berkarakter yakni: 1) Conscience (nurani), 2) Self-esteem (percaya diri), 3) Empathy (merasakan penderitaan orang lain), 4) Loving the good (mencintai kebenaran), 5) Self-control (mampu mengontrol diri), 6) Humility (kerendahatian). Moral Action adalah bagaimana membuat pengetahuan moral dapat diwujudkan menjadi tindakan nyata. Perbuatan atau tindakan moral ini merupakan hasil dari dua komponen karakter lainnya. Untuk memahami yang mendorong seseorang dalam perbuatan yang baik maka harus dilihat tiga aspek lain dari karakter yaitu kompetensi, keinginan, dan kebiasaan.

Orang yang berkarakter adalah orang yang konsisten antara pikiran dan tindakan, sebagaimana di dalam agama Islam disebutkan yaitu diucapkan dalam lisannya, dibenarkan dalam hatinya, dan dilakukan dengan tindakan yang nyata. Menurut Yahya Khan (2010:2) ada empat jenis pendidikan karakter yang selama ini dikenal dan dilaksanakan dalam proses pendidikan, sebagai berikut: 1) Pendidikan karakter berbasis nilai religious, yang merupakan kebenaran wahyu tuhan (konservasi moral). Dalam hal ini ada beberapa hal yang terkandung dalam nilai religius, seperti: a) Mengajar untuk selalu berpikir, b) Menguatkan nilai diri yang bertumpu pada aturan Tuhan yang termaktub dalam kitab suci, c) Menguasai perasaan, baik terhadap diri sandiri maupun terhadap orang lain, d) Membuka diri terhadap hubungan saling mempedulikan antar sesama, e) Mengembangkan diri untuk melayani dan memimpin. 
2) Pendidikan karakter berbasis nilai budaya, antara lain yang berupa budi pekerti, pancasila, apresiasi sastra, keteladanan tokoh-tokoh sejarah dan para pemimpin bangsa (konservasi lingkungan). 3) Pendidikan karakter berbasis lingkungan (konservasi lingkungan). 4) Pendidikan karakter berbasis potensi diri, yaitu sikap pribadi hasil proses kesadaran pemberdayaan potensi diri yang diarahkan untuk meningkatkan kualitas pendidikan (konservasi humanis).

\section{Metode Penelitian}

Penelitian ini menggunakan pendekatan kualitatif deskriptif. Pendekatan kualitatif deskriptif yaitu penelitian yang menggunakan pengumpulan data / informasi sebanyak-banyaknya mengenai gejala yang ada di tempat penelitian. Deskriptif berisikan gambaran tentang latar pengamatan orang, tindakan dan pembicaraan (Lexy, J. Moleong, 2002:3).

Tempat penelitian ini adalah di SDIT Nur Hidayah Surakarta. Subyek dalam penelitian ini adalah guru dan siswa-siswa SDIT Nur Hidayah, sedang yang menjadi informannya adalah Kepala Sekolah, Satpam, dan orangtua wali murid. Metode pengumpulan data berupa observasi, wawancara mendalam, dan dokumentasi.

Analisis data penelitian ini menggunakan metode non statistic dengan menggunakan metode interaktif yang dikembangkan Miles dan Huberman (1992:20) model ini bermakna bahwa proses mengorganisasi dan meruntut data dalam pola, kategori dan satuan uraian dasar sehingga dapat ditemukan tema. Langkah-langkah analisis dan model interaktif ini dapat dijelaskan sebagai berikut:

Pengumpulan data (data collection). Data-data yang diperoleh di lapangan dicatat atau direkam dalam bentuk diskriptif naratif, yaitu uraian data yang diperoleh dari hasil wawancara, observasi, dan dokumen-dokumen yang berkaitan dengan sistem pelaksanaan pendidikan karakter oleh lembaga sekolah. 1) Reduksi Data. Reduksi data merupakan prose pemilihan, pemusatan perhatian, pada penyerderhanaan, pengabstrakan dan transformasi data kasar yang muncul dari catatan lapangan. 2) Penyajian Data (data display). Pada tahap ini disajikan data hasil temuan lapangan dalam bentuk teks naratif, yaitu uraian tertulis tentang proses dan aktivitas pembiasaan cara berfikir dan menumbuhkembangkan karakter siswa dalam berperilaku. 3) 
Penarikan kesimpulan dan verifikasi (conclusion and verification). Penarikan kesimpulan dan verifikasi merupakan upaya mencari makna dari komponen-komponen data yang disajikan dengan mencermati pola-pola keteraturan, kejelasan, konfigurasi dan hubungan sebab akibat. Dalam melakukan kesimpulan dan verifikasi tentang proses dan aktivitas membiasakan cara berfikir siswa dan pembinaan karakter pada siswa dalam berperilaku.

\section{Pembahasan}

Bentuk-bentuk pendidikan karakter di SDIT Nur Hidayah Surakarta tidaklah tertulis secara langsung, tetapi keterangan dari misi SDIT Nur Hidayah menggambarkan bahwa lembaga tersebut telah melaksanakan dan menerapkan pendidikan karakter berbasis keagamaan. Sebagaimana juga telah diungkapkan oleh Kepala Sekolah Ari Puspitowati "pendidikan yang sesungguhnya haruslah menyentuh tiga aspek yaitu kognitif, afektif dan psikomotorik". Untuk itu kami memasukkan nilai-nilai pendidikan karakter di semua kegiatan sekolah termasuk di dalam ekstrakurikuler (Wawancara).

Bagi seluruh guru maupun karyawan yang ada di SDIT Nur Hidayah, pendidikan karakter itu bukan sesuatu yang asing bagi mereka, karena pada dasarnya setiap kegiatan apapun itu mereka dituntut untuk merealisasikan bentuk-bentuk pendidikan karakter seperti halnya hidup bersih, buang sampah pada tempatnya, berkata sopan dan ramah, tepat waktu, disiplin, berkata jujur, dan aspek-aspek yang lainnya.

Menurut bapak Waskito selaku WAKA Kurikulum SDIT Nur Hidayah menjelaskan bahwa "Program mentoring, mutabaah yaumiyah, pekan pembiasaan, SIDAK, kajian keputrian, sholat jenazah dan sholat ghaib ketika ada warga sekitar yang meninggal dunia, SOMG (Sosialosasi Orangtua Murid dan Guru) dan kegiatankegiatan yang lainnya yang bersifat harian dan mingguan merupakan kegiatan yang dilaksanakan secara intensif dan terstruktur."

Uraian di atas merupakan sejumlah program yang dimiliki oleh SDIT Nur Hidayah untuk membina siswa sesuai dengan visi misi yang telah disepakati. Untuk lebih memfokuskan pengkajian pembinaan pendidikan karakter berbasis keagamaan, maka hal tersebut dapat dikelompokkan menjadi dua cara yaitu: a) Terintegrasi dalam proses pembelajaran. Salah satu pembinaan pendidikan karakter di SDIT Nur Hidayah 
dilaksanakan dengan cara mengintegrasikan dalam setiap mata pelajaran yang disampaikan kepada peserta didik. Model pengajaran di SDIT Nur Hidayah untuk kelas satu dan dua menggunakan model pembelajaran tematik. Dengan menggunakan model tematik, maka guru lebih mudah dan luwes di dalam mengintegrasikan pendidikan karakter di setiap pembelajarannya.

Sebagai contoh, ketika menerangkan tema "Aku dan Keluargaku”, guru dapat menerangkan tema tersebut dengan memasukkan dan menggabungkan antara nilai-nilai yang diajarkan dalam pelajaran PPKN dan nilai Agama. Misalnya ketika menerangkan tema tersebut guru menyampaikan tentang kerukunan, saling menghormati dan menghargai serta saling gotong royong dalam keluarga (nilai PPKN). Kemudian guru juga dapat mengkorelasikan dengan pelajaran agama, misalnya seorang anak harus berbakti pada orangtua dan mendoakan kedua orang tua. Disini guru juga dapat mengajarkan kepada anak tentang bagaimana melafalkan dan menghafalkan doa untuk kedua orangtua.

Pendidikan karakter yang diintegrasikan dalam setiap materi pembelajaran tersebut tidak hanya merupakan teori saja tanpa tindakan yang berarti, namun juga dilaksanakan dalam keseharian di sekolah. Hal ini terlihat dalam keseharian siswa di sekolah misalnya setiap memasuki gedung mereka harus melepas sepatu dan menempatkannya di rak masing-masing, setiap sebelum masuk siswa-siswa yang piket membersihkan ruang kelas dan setiap melihat ada sampah yang ada mereka memungutnya dan memasukkan ke dalam bak sampah. Selain dilihat dari keseharian siswa, dapat pula dilihat dari keadaan area yang bersih, tanaman terjaga dengan baik dan tertata dengan indah (observasi dan wawancara dengan beberapa siswa kelas 3B).

Pada kesempatan lain ketika guru menerangkan tema "Aku dan Sekolahku", guru menyampaikan kepada siswa bagaimana adab seorang siswa terhadap guru, adap terhadap karyawan, dan masyarakat sekolah yang lain. Selain itu guru juga menyampaikan materi tentang adab bergaul dengan sesama siswa, dan kasih sayang terhadap teman serta saling toleransi. Sebagimana penjelasan ibu Minuk yang mana selain menjadi wali kelas, beliau juga ketua koordinator paralel kelas satu bahwa "Memang pendidikan karakter untuk kelas satu bersifat tematik sesuai dengan kurikulum Diknas, sebagai contohnya dengan tema "Aku dan Sekolahanku” di 
dalamnya kami selaku wali kelas membimbing siswa untuk menjaga lingkungan sekolah, dari menjaga kebersihan, kedisiplinan, rasa tanggung jawab untuk menjanga lingkungan sekolahnya."

b) Program-program pendidikan karakter di luar mata pelajaran seperti: 1)

Pekan Pembiasaan. Program ini dilakukan sesuai dengan tema-tema pembiasaan yang telah ditentukan dari pihak kesiswaan. Tema-tema tersebut meliputi tema disiplin, rajin ibadah, kebersihan, adab makan dan minum, tebar salam, dan hemat. Dalam pelaksanaannya, pertama dari bidang kesiswaan melihat kondisi secara langsung keadaan siswa-siswanya serta menentukan salah satu tema yang dianggap tepat dan sesuai di dalam pembentukan karakter siswa, kemudian dibuat surat edaran yang langsung ditujukan kepada para wali kelas dan ditindaklanjuti pelaksanaan bersamasama dengan guru . Karena kantor wali dan asisten wali kelas berada di kelas yang diampu masing-masing dan yang setiap saat dapat memantau murid saat pembelajaran, maka wali kelas dan asisten wali kelas yang akan melakukan kontrol terhadap pelaksanaannya.

Misalnya dalam dua pekan tesebut temanya adalah kebersihan, maka guru harus selalu mengingatkan dan membimbing siswa untuk menjaga kebersihan, baik kebersihan badan maupun lingkungan. Contohnya guru harus mengajari dan membiasakan siswanya untuk mencuci tangan sebelum makan, membuang sampah pada tempatnya, dll. Jika tema yang dipilih tersebut adalah aksi hemat, maka guru harus mendidik dan membiasakan siswa-siswanya untuk berhemat, contohnya hemat air waktu berwudu, hemat jajan di sekolah (siswa dilarang jajan di luar koperasi sekolah, dan siswa dilarang membawa uang jajan. Jadi ketika ingin jajan hanya menunjukkan voucer jajan di koperasi (Wawancara).

Pemaparan di atas adalah gambaran umum mengenai pekan pembiasaan di SDIT Nur Hidayah. Adapun program Pekan Pembiasaan secara rinci dibagi menjadi beberapa tema yaitu: i) Tema kebersihan. Kebersihan adalah hal pertama yang sangat diperhatikan sebelum sholat atau puasa, dan kebersihan adalah sebagian dari iman, tema kebersihan ini sangat diperhatikan oleh pihak sekolah untuk menanamkan pola hidup bersih siswa dalam kehidupan sehari-hari. Bentuk lain dalam pekan kebersihan ini adalah masing-masing guru diberikan surat edaran dari pihak kesiswaan untuk 
menyampaikan tema kebersihan, selain itu pekan ini juga bisa dilaksanakan secara kondisional melihat situasi siswa yang mengalami kekendoran dalam hal kebersihan, sebagai kontrol guru terhadap kebiasaan baik siswa (wawancara). Adapun inisiatif yang diciptakan guna meningkatkan semangat siswa dalam menjaga untuk hidup bersih maka pihak sekolah untuk beberapa jangka waktu akan mengadakan perlombaan kebersihan antar kelas, mulai dari kelas 1 sampai kelas 6. Di kelas pun telah dibentuk tim kebersihan, setiap harinya. Di samping itu terdapat sebuah tata tertib yang sangat mendidik siswa untuk menjaga kebersihan adalah kewajiban untuk melepaskan sepatu saat memasuki area sekolah dan meletakkan sepatu di rak yang telah disediakan. Apabila ada siswa yang melanggar maka akan mendapatkan sanksi dari pihak sekolah. Salah seorang siswi yang bernama Asma mengatakan: "peraturan melepas sepatu sudah sejak kelas satu dulu, jadi dah terbiasa, kan lantainya biar bersih, dan kalau ada temen yang bandel nanti dapat sanksi kok".

ii) Tema Kedisiplinan. Kedisiplinan adalah karakter penting yang harus ditanamkan kepada siswa sedini mungkin. Karena itu, di dalam mengajarkan dan mendidik kedisiplinan siswa SDIT Nur Hidayah, pihak kesiswaan mengadakan program pekan pembiasaan yang salah satu temanya adalah kedisiplinan (wawancara Ibu Lely). Program dari tema kedisiplinan tersebut antara lain SIDAK (Inspeksi Mendadak), pengecekan kelngkapan seragam dan atribut, pendisiplinan tata tertib.

Inspeksi mendandak atau yang sering disingkat dengan SIDAK tersebut bertujuan untuk mengontrol kedisiplinan siswa. Inspeksi tersebut dilaksanakan minimal satu kali dalam dua bulan. Dalam inspeksi ini petugas yang bertugas untuk menertibkan melaksanakan razia secara mendadak. Ketika ada siswa yaang membawa barang-barang yang tidak diperbolehkan untuk dibawa ke sekolah (misalnya: hand phone, uang jajan, majalah atau tabloid-tabloid porno, dll), maka petugas akan menyita dan memberikan hukuman sesuai ketentuan yang telah ditetapkan pihak sekolah (wawancara Ibu Ari Puspitowati).

iii) Rajin Ibadah. Setiap hari siswa-siswi SDIT Nur Hidayah dibina mulai dari ibadah wajib sampai ibadah sunnah. Oleh karena itu, untuk membina masing-masing siswa dengan jenjang berbeda maka terdapat program-program untuk masing-masing kelas: Pada jenjang kelas 1 dan 2 ini, para siswa lebih ditekankan pada pelatihan ibadah 
berupa program yang bernama "sadar sholat" yang mana program tesebut dilaksanakan setiap hari di waktu dhuhur. Program yang mana setiap siswa melaksanakan sholat di kelas masing-masing serta yang bertugas sebagai muazin adalah siswa yang mendapat giliran, selain itu imam sholat juga dipimpin oleh salah satu siswa yang bertugas ( hasil wawancara dengan Ibu Ari Puspitowati).

Hal ini pun dibenarkan dan dilengkapi penjelasannya oleh waka kesiswaan yaitu Leli Firli Rohmani S.Psi, beliau manyatakan bahwa setiap pelaksanaan sholat berjamaah telah dijadwalkan dari pihak kesiswaan, siapa yang mendapat bagian menjadi muadzin dan siapa yang mendapat giliran menjadi imam sholat. Dengan demikian, program sadar sholat ini bertujuan agar siswa memiliki kesadaran dalam beribadah, khususnya sholat.

Untuk program pembiasaan sebagai kelanjutan dari kelas dua, maka untuk kelas 3 dan 4 terdapat hal yang sedikit berbeda dengan pembiasaan sebelumnya, dilihat dari sistematika pengaturan sholat, siswa putra dan putri dipisahkan tidak dalam satu ruangan yang sama, siswa putra sholat di ruangan laboraturium IPS sedangkan siswa putri di aula, karena pada jenjang ini siswa telah memasuki umur wajib sholat maka saat sholat akan diimami oleh guru (wawancara dengan bu Lely).

Bagi siswa yang terlambat dalam melaksanakan shalat maka terdapat hukuman-hukuman tersendiri, seperti yang dipaparkan oleh Farah siswi kelas 3 A: "Kalau ada yang telat sholatnya temen-temen yang laki-laki dikunci di laboraturium IPS bunda, sampai satu jam pelajaran, alternatif lainnya yaitu bajunya dikasih tempelan yang bertuliskan telat sholat".

Sebagaimana hasil wawancara tersebut maka siswa yang terlambat dalam melaksanakan shalat maka akan diberi sebuah label yang bertuliskan "Telat Sholat" yang ditempel di punggung sampai jam sekolah usai. Selain itu ada pula hukuman yang diberikan kepada siswa putra yang katahuan telat sholat akan dikunci di Laboraturium IPS selama satu jam pelajaran. Hal ini bertujuan untuk membina serta meningkatkan kesadaran shalat siswa.

Untuk siswa kelas 5 dan 6, mereka semua melaksanakan sholat di masjid, siswa laki-laki di lantai dua dan siswa perempuan di lantai 3 yang masih satu mimbar. 
Setelah selesai sholat, siswa-siswanya diajak berdoa bersama-sama dan setelah itu diberi sedikit tausiyah dan motivasi.

iv) Adab Makan. Dengan corak SDIT Nur Hidayah adalah full day maka untuk memenuhi kabutuhan jasmani dengan makan siang catering, sebelum shalat duhur. Makanan siswa ditempatkan dalam sebuah tempat makan yang terbuat dari plastik. Biaasanya pada pukul 10.45 pesanan catering tiba, untuk kelas 1 sampai kelas 4 , kotak makanan masing-masing ditaruh di depan kelas, sedangkan kelas 5 dan 6 ditaruh di aula. Saat waktu makan siang tiba maka seluruh siswa mancuci tangan terlebih dahulu setelah itu duduk berjajar dan berhadap-hadapan di depan kelas masing-masing. Para siswa diperbolehkan untuk membawa makanan atau lauk tambahan sendiri dari rumah masing-masing.

Setelah selesai makan, siswa mengembalikan tempat makanan di tempat semula dengan rapi. Selain itu terdapat sebuah peraturan yaitu larangan untuk membeli makanan dari luar sekolah. Bagi siswa yang ketahuan membeli makanan di luar akan diberi sanksi dari wali kelas. Sebagai alternatif lain untuk memenuhi kebutuhan siswa agar tidak jenuh dalam pola makanan, maka pihak sekolah bagian koperasi memiliki sistem pembelian voucher bagi anak yang ingin membeli makanan di koperasi, karena makanan yang dijual koperasi memiliki standar dan ijin dari pihak sekolah. Jadi seorang siswa membeli voucher sebagai kartu kredit pembelian (observasi).

2) Mentoring, merupakan sebuah kegiatan yang sudah tidak asing lagi bagi kita semua. Kalau kita kembalikan ke zaman dahulu sebenarnya kata yang dipakai bukan mentoring, tetapi halaqoh. Sistem ini sudah dipakai sejak zaman dahulu dengan pemahaman bahwa guru menjadi Teacher Center. Dalam hal ini guru bertindak sebagai penceramah dan pemegang penuh kegiatan tersebut. Halaqoh ini terdiri dari beberapa orang yang duduk melingkar dengan satu guru yang juga duduk di tempat tersebut. Sistem ini sangat bagus untuk diterapkan, karena seorang guru dapat mengontrol siswa secara langsung.

SDIT Nur hidayah Surakarta merupakan sebuah lembaga sekolah dasar yang berusaha menggabungkan berbagai sistem pembelajaran, metode belajar, dan lain-lain. Dalam hal ini SDIT Nur Hidayah mengadopsi halaqoh/mentoring. Model ini diterapkan 
dengan menggunakan berbagai inovasi-inovasi terbaru yang sebelumnya belum dilakukan.

Jam sepuluh pagi terlihat siswa-siswa perempuan yang jumlahnya 9 orang sedang duduk melingkar yang salah satunya adalah guru. Semua siswa memegang AlQuran dan setelah itu membaca secara bersama-sama dan dilanjutkan berbagai kegiatan yang membuat anak merasa dekat dengan guru mentornya. Kegiatan-kegiatan yang diprogramkan dengan inovasi sedemikian rupa membuat siswa menjadi nyaman, meskipun ada beberapa sub kegiatan yang mereka tidak sukai (observasi).

Semua siswa kelas 5 dan 6 diwajibkan untuk mengikuti kegiatan mentoring, karena kegiatan tersebut merupakan kegiatan yang sudah dimasukkan ke dalam Program Pembinaan Siswa Intensif di SDIT Nur Hidayah. Kedudukan guru mentoring bermacam-macam, terkadang menjadi penceramah, terkadang menjadi sahabat siswa atau sebagai sarana sharing, terkadang sebagai pengevaluasi. Hal inilah yang dibutuhkan oleh semua siswa di waktu sekarang ini, karena siswa tidak merasa tertekan dan membuat siswa merasa nyaman di dalam mengikuti rangkaian sub acara mentoring.

Salah satu siswa kelas 5 SDIT Nur Hidayah yang bernama Fio menceritakan bahwa dia selalu mengikuti program-program yang diselenggarakan oleh pihak sekolah diantaranya mentoring, dikegiatan tersebut dia setoran hadist, diberikan motivasi, dievaluasi setiap guru mentoring mengenai kesehariaannya. Yang paling dirasakan adalah diberikan tanggung jawab untuk hafalan doa, surat-surat pendek, dan mengisi kegiatan harian (wawancara).

Pernyataan ini didukung oleh bapak Waskito selaku WAKA Kurikulum SDIT Nur Hidayah menjelaskan bahwa ada berbagai program yang ada di sekolah tersebut. Khusus untuk program mentoring dilaksanakan oleh satu guru penanggung jawab kegiatan mentoring yang mendampingi sembilan orang siswa. kegiatan ini dilaksanakan satu minggu sekali dengan berbagai sub pembahasan yang sudah terstruktur di dalamnya. Sebagai contoh sub bagiannya antara lain, setoran hafalan, sharing, diskusi, pemberian motivasi (wawancara).

3) Mutaba'ah Al-Yaumiyah. Program ini diperuntukkan kepada semua siswa kelas satu sampai kelas enam, maka dari itu program ini termasuk ke dalam Program Pembinaan Intensif. Mutaba'ah Al-yaumiyah ini diimplementasikan di dalam buku 
khusus yang di bawa oleh wali kelas dengan koordinasi langsung dengan orangtua wali murid. Untuk kelas lima dan enam, buku khusus mutaba'ah al-yaumiyah dibawa dan diisi langsung oleh siswanya sendiri mengenai kegiatan sehari-harinya. Untuk mengontrol kegiatan tersebut, wali kelas siswa kelas satu dan kelas dua beserta orangtua wali siswa bertanggung jawab penuh dan saling koordinasi.

Pak Chalimi selaku orangtua wali siswa mengatakan bahwa kegiatan yang ada di SDIT Nur Hidayah sangat baik, bermutu dan menjadikan anak bertanggung jawab. Dia mengatakan bahwa anaknya mengalami banyak peningkatan dalam beberapa aspek diantaranya dalam kedisiplinan, sopan santun kepada orangtua, kebersihan, dan dia seringkaali disuruh menyimak anaknya didalam hafalan doa maupun hafalan surat-surat pendek (wawancara).

Sebagian besar guru SDIT Nur Hidayah Surakarta menyadari akan pentingnya pendidikan karakter, meskipun sekolah mereka tidak secara langsung mengatasnamakan pendidikan karakter, tetapi mereka memaknai pendidikan karakter sebagai segala sesuatu yang mereka laksanakan ketika mengajar maupun tidak mengajar, di rumah maupun tidak di rumah, dll. Dan sudah menjadi kewajiban pertama seorang guru di dalam menanamkan akhlak yang mulia kepada siswa-siswanya dengan desain/programprogram yang maksimal dan terkontrol.

\section{Kesimpulan}

Berdasarkan data dari penelitian yang diperoleh, maka dapat diambil kesimpulan mengenai pendidikan karakter berbasis keagamaan di SDIT Nur Hidayah Surakarta berupa program-program yang secara langsung diintegrasikan dan diinternalisasikan ke dalam setiap pembelajaran di dalam kelas maupun di luar kelas. Meski terlihat sangat sederhana, namun dari pembiasaan, kedisiplinan, tanggungjawab yang kecil dengan kontrol yang akurat menjadikan siswa memiliki karakter yang kokoh. Program tersebut dapat digolongkan menjadi 2 diantaranya: 1) Pendidikan karakter yang terintegrasi dalam proses pembelajaran. Dalam proses pembelajaran pendidikan karakter yang ditanamkan tidak sekedar teori tertulis, namun lebih menitikberatkan pada keteladanan, nasehat-nasehat serta motivasi.

| Volume. 1, No. 1, Januari-Juni 2016 
2) Adanya program-program di luar proses pembelajaran yaitu: a) Pekan Pembiasaan. Program ini merupakan pembinaan yang di dalamnya terdapat tema-tema yang mempunyai nilai-nilai karakter Islami, seperti program dengan tema disiplin, rajin ibadah, kebersihan, adab makan dan minum, dan hemat. Dalam pelaksanaannya, bidang kesiswaan melihat kondisi para siswa-siswanya, setelah itu menentukan salah satu tema yang dianggap tepat dan sesuai dengan kondisi yang sedang terjadi di waktu itu. Kemudian bekerjasama dengan wali kelas serta guru-guru untuk menindaklanjuti tema tersebut melalui tindakan langsung maupun melalui materi. b) Mentoring dan Mutabaah Al-Yaumiyah. Mentoring dan Mutabaah Al-Yaumiyah adalah program yang berfungsi sebagai pengontrol serta kelanjutan dari pendidikan karakter yang lebih dititik beratkan pada pembinaan akhlak. Untuk mentoring kelas 1-4 dilaksanakan setiap hari pada pagi hari oleh wali kelas masing-masing. Namun untuk kelas 5 dan 6 diadakan seminggu sekali dengan membentuk halaqoh yang di dalamnya beranggotakan 9-10 siswa. Sedangkan Mutabaah Al-yaumiyah lebih pada pengecekan rutinitas ibadah dalam bentuk rapor.

Adapun saran yang bisa disampaikan untuk meningkatkan kualitas kedepannya adalah sebagai berikut: 1) Kepala sekolah serta guru harus menjabarkan nilai-nilai karakter secara rinci, atau setiap nilai karakter harus ada indikatornya agar lebih mudah di dalam pengontrolannya maupun pengevaluasiannya. 2) Bagi para peneliti harus lebih benyak mengembangkan penelitiannya di sekolah-sekolah yang berbasis agama-agama, karena tidak dapat dipungkiri bahwasannya ia merupakan sumber nilai-nilai yang harus dimunculkan serta dikembangkan di dalam membentuk karakter manusia. 


\section{Daftar Pustaka}

Bambang Q-Anees dan Adang Hambali. 2008. Pendidikan Karakter Berbasis AlQuran. Bandung: Simbiosa Rekatama Media

Kemendiknas. 2010. Pembinaan Pendidikan Karakter di Sekolah Menengah Pertama. Jakarta

Lexy J. Moleong. 2004. Metodologi Penelitian Kualitatif Bandung: Remaja Rosda Karya.

Lickona, T. 1992. Educating for Character, How Our Schools Can Teach Respect and Responsibility. New York: Bantam Books.

M. Furqon Hidayatullah. 2010. Pendidikan Karakter Membangun Peradaban Bangsa. Surakarta: Yuma Pustaka

M. Furqon Hidayatullah. 2010. Guru Sejati: Membangun Insan Berkarakter Kuat dan Cerdas. Surakarta: Yuma Pustaka

Mansur Muslich. 2011. Pendidikan Karakter: Menjawab Tantangan Krisis Multidimensional. Jakarta: Bumi Aksara

Nurul Zuriah. 2008.Pendidikan Moral dan Budi Pekerti dalam Prespektif perubahan. Jakarta:Bumi Aksara

PP Nomor 55 Tahun 2007 tentang Pendidikan Agama dan Keagamaan

Ratna Megawangi. 2003. Pendidikan Karakter Untuk Membangun Masyarakat Madani. Jakarta. Institut Pengembangan Pendidikan Karakter.

Suparno, Paul dkk. 2010. Pendidikan Budi Pekerti di Sekolah. Yogyakarta: Kanisius

Yahya Khan.2010.Pendidikan Karakter berbasis Potensi Diri.Yogyakarta: Pustaka Publishing

| Volume. 1, No. 1, Januari-Juni 2016 
56 Fauzi Annur

Pendidikan Karakter Berbasis Keagamaan (Studi Kasus di SDIT Nur Hidayah Surakarta) 